\title{
Challenges and Issues That Are Faced by the Sri Lankan School Library Staff (2000-2016 period)
}

\author{
Prasanna Ranaweera \\ University of Colombo, Sri Lanka
}

\begin{abstract}
This study focuses on challenges and issues faced by the Sri Lankan School Library staff recruited under the General Education Project 2 (GEP 2). The study was conducted in order to identify the pros and cons of the GEP 2 Library staff training project. 4000 teacher librarians were recruited to the school libraries under the GEP 2 Project. The National Institute of Library and Information Science (NILIS), University of Colombo, was established under this project. In 2003 NILIS introduced Masters, Post-graduate Diplomas, Diploma and Certificate courses in Library Sciences, in order to train the newly recruited teacher librarians and support staff. This study proposes to reveal the main factors which contributed towards the inadequate number of students for the NILIS courses, which were mainly due to the policies of the government regarding staff training, and the school libraries in Sri Lanka. This study was carried out with the available written documents, communications, and face to face interviews, with the relevant parties. NILIS is struggling to improve the training of school library staff throughout the island in numerous ways, in spite of the red notice by the authorities to close down the Institute. Subsequently due to the best practice of NILIS it was possible to convince the officials of the Ministry of Education regarding the importance of School libraries, and staff training, which resulted in the increase of the number of students from 26 in 2013, to 250 in 2016.
\end{abstract}

Key words: Teacher Librarians, School library, General Education, Teacher Librarians, Sri Lanka

\section{INTRODUCTION}

According to the Sri Lankan school census (2016) there are 10162 government schools in the island. The number of students who study in these schools from grade one to thirteen are 4,143,330. All these schools have school libraries in different capacities. Before 2000 the school libraries in Sri Lanka were isolated units and were not adequately equipped with the necessary information resources or staff. The school teaching and learning took place without the usage of information resources. The General education reforms implemented in Sri Lanka since 1995 on wards with the world bank assistance, aimed to develop student centered education, instead of teacher centered education. The development of the Sri Lankan general education system consisted of 8 components. One of the eight components of the General Education Project 2 (GEP2) was to develop School Libraries and Resource Centers (SLRCs). The GEP2 project totaled US\$ 83.4 million, according to the 2006 WB project completion report, with US\$ 5.9 million initially allocated for the library component (Wijetunge, 2003). This Library component aimed to provide books, equipment, furniture, and training for staff in library management; IFLA/UNESCO (2006) outlines in its School Library Manifesto the mission, goals, funding, staffing and operations and management of school libraries. The manifesto states the school library is to 'provide information and ideas that are fundamental to functioning successfully in today's information and knowledge-based society. The school library equips students with life-long learning skills and develops the imagination, enabling them to live as responsible citizens' (p.1). Therefore, the school libraries play a very important role in the general education system of Sri Lanka.

According to the World Bank plan, establishing 4,000 School Library Resource Centers and recruiting 4,000 teacher Librarians were given priority under the library component. The National 
Institute of Library and Information Sciences (NILIS) was established within the University of Colombo, with the primary objective of training, awarding certificates, Diplomas and post-graduate degrees for the school library staff. 4000 graduates were selected to be trained as Teacher Librarians (TL) under the GEP2 project, in order to assist with the government general education reforms. These TLs were expected to assist with the implementation of resource-based teaching and learning at school level. At the same time the School Library Development Unit (SLDU) was established within the Ministry of Education to supervise the SLRCs and to carry out the library development successfully. A model School Library Resource Centre was built in each province, in addition to the 4000 SLRCs. This model library, normally a two-storied building, comprised of books and printed materials on one floor and audio-visual material and computers/internet facilities in two sections on the other floor. The model SLRC's role is to be an example to the other SLRCs of the province. Today, out of the nine model libraries, only one is operating fully. That is the Rangiri Dambullla National School's SLRC in the Central Province of Sri Lanka. The other model SLRC's are not functioning satisfactorily. Some are not well equipped and not managed by teacher librarians. They are namely, 1. Jaffna Central College 2. Debarawewa National School 3. Galgamuwa National School 4. Princes of Wales College, Moratuwa 5. Medirigiriya National School 6. Aligar National School, Eravur 7. Embilipitiya National School 8. Wellassa National School, Bibile.

\section{NILIS CONTRIBUTION TOWARDS SCHOOL LIBRARY STAFF DEVELOPMENT IN SRI LANKA}

NILIS commenced its educational programmes in 2002, by conducting lectures for the newly recruited teacher librarians. Accordingly, 5-day lecture programs were conducted island wide, to raise awareness among the teacher librarians regarding the new concepts introduced to the school library sector. Since the 5-day training programme was inadequate to obtain a thorough knowledge about the new concept and to practice the new reforms, in 2003, NILIS introduced postgraduate courses for the teacher librarians. Accordingly, Masters and postgraduate diploma courses in school librarianship were commenced. The expertise of local and international professionals in the field of education as well as library and information sciences was obtained in the preparation of the curriculum for the above courses. Later on, NILIS commenced courses for the other staff in the school library sector, such as diploma (DSL)and certificate courses in librarianship (CSL).

Initially, the school library in Sri Lanka functioned as a unit which did not make a direct contribution towards the school curriculum, or the teaching-learning process. But the new courses had been designed based on the concepts of Resource based, competency based and information literacy learning. When applying the above concepts to the enhancement of the quality of the teaching-learning process the school library becomes an essential center in the school. Thus, the school library is being gradually transformed into a learning resource center. The NILIS courses have introduced four functions which should be carried out by the school library/learning resource center, which will comprise the library, audio visual unit, and the computer center.

i. $\quad$ Teaching information literacy skills

ii. Collaborative teaching (subject teacher, teacher librarian, computer science teacher and teacher in charge of audio-visual unit)

iii. Direct contribution to the Extended learning process (assignments, exercise, projects)

iv. Appreciation of culture and literature

v. School library management

In order to achieve the above, a new information literacy model known as "empowering 8" which has been designed using the expertise of local and international professionals was introduced by NILIS to the school library sector in 2004. The model consists of 8 steps which contain a number of information literacy skills. The responsibility of the teacher librarian is to guide the students to attain the information literacy skills contained in the model. Subject teaching by the teachers, and completing of assignments and projects by the students could be achieved fruitfully by using this model. The teachers 
who have obtained postgraduate qualifications from the NILIS are engaged in the invaluable task of implementing this new concept within the school curriculum a reality.

However, the mere knowledge of the teacher librarians is inadequate to effectively introduce and implement such concepts within the school library sector. To enable this endeavor to be a success all individuals in the education sector should be made aware of the concepts. Taking these factors into consideration, NILIS, during the past decade has conducted awareness raising programs regarding the concepts, at national, zonal, district, and area levels, for principals, education officers, subject directors, instructors and subject teachers. Accordingly, it can be observed that the school library is being gradually integrated into the teaching-learning process within the school curriculum.

The following table briefly gives information on such programs conducted in 2015 .

\begin{tabular}{|l|l|}
\hline Subject & $\begin{array}{l}\text { Number } \\
\text { of } \\
\text { Partici- } \\
\text { pants }\end{array}$ \\
\hline NILIS Symposium 2015(13.11.2015) & 144 \\
\hline International Workshop on Instructional Pedagogy for Librarians" & 31 \\
\hline Three day workshop on Information Literacy for Library Staff University of Jaffna & 48 \\
\hline Three day training programme for the NILIS visiting Lectures & 11 \\
\hline Training Programme for Principals and Teacher Librarians in Denuwara Educational Zone & 40 \\
\hline Training Programme for Principals and Teacher Librarians in Matale Educational Zone & 40 \\
\hline Training Programme for Principals and Teacher Librarians in Kandy Educational Zone & 40 \\
\hline Training Programme for Principals and Teacher Librarians in Katugastota Educational Zone & 40 \\
\hline Training Programme for Principals and Teacher Librarians in N'Eliya Educational Zone & 40 \\
\hline Training Programme for Principals and Teacher Librarians in N'Eliya Educational Zone & 40 \\
\hline Training Programme for Principals and Teacher Librarians in Hatton Educational Zone & 40 \\
\hline Training Programme for Principals and Teacher Librarians in Kothmale Educational Zone & 40 \\
\hline Training Programme for Principals and Teacher Librarians in GampolaEducationsl Zone & 40 \\
\hline Training Programme for Principals and Teacher Librarians in Walapane Educational Zone & 40 \\
\hline Training Programme for Principals and Teacher Librarians in Walapane Educational Zone & 40 \\
\hline Training Programme for Principals and Teacher Librarians in Naula Educational Zone & 40 \\
\hline Training Programme for Principals and Teacher Librarians in Wilgamuwa Educational Zone & 40 \\
\hline Training Programme for Principals and Teacher Librarians in Galewela Educational Zone & 40 \\
\hline $\begin{array}{l}\text { Training Programme for Principals and Teacher Librarians in Hanguranketha Educational } \\
\text { Zone) }\end{array}$ & 40 \\
\hline Training Programme for Principals and Teacher Librarians in Theldeniya Educational Zone & 40 \\
\hline $\begin{array}{l}\text { Training Programme for Principals and Teacher Librarians in Gampola/Kothmale } \\
\text { Educational Zone }\end{array}$ & 40 \\
\hline
\end{tabular}

During the past decades, the concept of reading has undergone tremendous transformation, which extends from reading traditional printed matter to surfing the internet. NILIS has conducted a number of workshops to address this issue. Of these, the programs conducted in the Uva province for Science teachers, on reading printed matter and surfing the internet is exceptional.

It is a well-known fact that there are vast inequalities in the results of the G.C.E. (A.L. ) examination in the different provinces. The Siyambalanduwa education zone in the Uva province is one with a very low achievement level at the GCE (A.L.) examination. According to a decision taken by NILIS, a 3-day workshop was held as an initial program in 2015, to improve the achievement of these students. The use of the "empowering 8 " information literacy model in the teaching-learning process which centred around the library and learning resource center was demonstrated at the workshop. The principals of the schools in the Siyambalanduwa education zone (which had A/L classes), teachers teaching in the science, commerce and arts streams, and teacher librarians participated in this program, for which the resource personnel were the academic staff of NILIS. Following the workshop a special 
training program on information literacy skills will be held for the new students entering the A/L classes in June 2015. It is hoped to assess the progress of the students after conducting the program for two months. Developing the Handbook for TL and trainers guide, conducting a five-day training programme for the 2800 TLs, Conducting over 15 short term and long term programmes were the key functions of NILIS.

\section{PROBLEM STATEMENT}

The Teacher Librarians or library staff in the school libraries need to be well trained to carry out the following tasks in the schools.

- $\quad$ Teaching information literacy skills

- Collaborative teaching (subject teacher, teacher librarian, computer science teacher and teacher in charge of audio-visual unit)

- $\quad$ Direct contribution to the Extended learning process (assignments, exercise, projects)

- $\quad$ Appreciation of culture and literature.

- $\quad$ School library management

But the teacher librarians who have been recruited since 2003 (around 4000) have relinquished their positions due to the lack of promotional schemes and recognition by the authorities. In 2016 the Director, School Library Development Unit, Ministry of Education informed verbally that there are only a few teacher librarians, less than 150, in the schools, and that the majority of libraries are looked after by the other staff or the teachers. While the NILIS was training teacher-librarians, the Ministry of Education failed to include a new cadre for teacher-librarians in the Teachers' Service minute, which governs teacher qualifications, promotions, service requirements, eligibility for leave etc, for all teachers in the country. Cabinet approval was received on 10.08.2009 to include the NILIS professional qualifications of the teacher librarians in the Teachers' Service minute. But so far the NILIS qualifications have not been incorporated into the Teachers' Service Minute, resulting in severe drawbacks in the newly introduced concept of teacher librarian. Consequently, the recruited teacher librarians changed their role to teachers, and unqualified library staff or part time teachers are looking after the libraries, which has resulted in the school libraries not playing a role in the teaching learning process within the school curriculum. NILIS was doing its level best with a lot of communication, meetings and advocacy programmes to rectify the scenario but still no solution has been reached.

\section{DATA ANALYSIS}

This study reveals the main factors which contributed towards the inadequate number of students who registered for the courses, which were the weak policies of the government regarding staff training and the school libraries in Sri Lanka. This study was carried out with the available written documents, communications, and face to face interviews, with the relevant parties of the Ministry of EducationSchool Library Development Unit (SLDU), NILIS academic staff members, and teacher librarians who received NILIS qualifications. The main reasons attributed by teacher librarians who passed out from NILIS, to giving up their positions were; less recognition in the school, unable to get promotions, no opportunities for the exam duties and paper marking, being responsible for any loses in the library, unlike teachers they have to wait longer hours in the school, no teaching periods are given to them, they are not given opportunities to practice what they learn at NILIS, and etc. The Ministry of Education too is not interested in the concept of teacher librarian, and they wish to run the library with the other clerical staff or teachers on a part time basis.

\section{CONCLUSION}

The main areas that were focused on in this study was why this valuable school library staff training project was unsuccessful, and how NILIS is struggling to improve the training of school library staff throughout the island in numerous ways, in spite of the red notice by the authorities to close down the Institute. Subsequently due to the best practice of NILIS it was possible to convince the officials of 
the Ministry of Education regarding the importance of School libraries, and staff training, which resulted in the increase of the number of students from 26 in 2013, to 250 in 2016. In addition to that NILIS conducted a large number of short term training programmes for the school principals, teachers, and library staff, regarding the usage of the school libraries for the teaching learning process.

However, the mere knowledge of the teacher librarians is inadequate to effectively introduce and implement such concepts within the school library sector. To enable this endeavour to be a success all individuals in the education sector should be made aware of the concepts. Taking these factors into consideration, NILIS during the past decade, has conducted awareness raising programs regarding the concepts, at national, zonal, district, and area levels for principals, education officers, subject directors, instructors and subject teachers. Accordingly, it can be observed that the school library is being gradually integrated into the teaching-learning process within the school curriculum.

\section{REFERENCES}

ILFA/UNESCO. (2006). ILFA/UNESCO school library manifesto: The school library in teaching and learning for all. Retrieved 7 June, 2007, from http://www.ifla.org/VII/s11/pubs/manifest.htm

National Institute of Library and Information Science. (2016). NILIS annual reports 2002-2016. Colombo, Sri Lanka: University of Colombo.

Ranaweera, P. \& Alahakoon, U. (2015). Role of NILIS to develop the Library and Information Science Education in Sri Lanka, National Library $25^{\text {th }}$ Anniversary Commemorative Volume. Colombo, Sri Lanka: National Library and Documentation Services Board.

Ministry of Education. (2016). School census preliminary reports 2016. Colombo, Sri Lanka: Ministry of Education Sri Lanka. Retrieved $15 \quad$ March, 2017 from http://www.moe.gov.lk/english/images/Statistics/stat2015-16/2016 new3.pdf

Wijetunge, P. (2003). Recent general education policy reforms and their impact on LIS education. Journal of the University Librarians Association of Sri Lanka, 10. 